\title{
Antimicrobial Activity of Propolis from Tabora and Iringa Regions, Tanzania and Synergism with Gentamicin
}

\author{
Deborah K. B. Runyoro*' Olipa D. Ngassapa, Alex Kamugisha \\ Department of Pharmacognosy, School of Pharmacy, Muhimbili University of Health and Allied Sciences (MUHAS), Dar es Salaam, Tanzania.
}

\begin{tabular}{|c|c|}
\hline ARTICLE INFO & ABSTRACT \\
\hline Article history: & \multirow{7}{*}{$\begin{array}{l}\text { Antimicrobial resistance (AMR) is among the threats to global public health, with developing countries being } \\
\text { mostly affected. The AMR has undermined development of new antimicrobial agents by pharmaceutical } \\
\text { industries despite new emerging infections. This necessitates a search for antimicrobial agents from resources } \\
\text { available in developing countries. This study, therefore, aimed at assessing antimicrobial activity of two propolis } \\
\text { samples from Iringa and Tabora, Tanzania. Ethanolic extracts of the two propolis samples were tested against } \\
\text { standard microorganisms including, Gram +ve and Gram -ve bacteria and yeasts by determination of MICs } \\
\text { using broth microdilution method. Synergism with Gentamicin was also assessed for one of the samples. } \\
\text { Furthermore, HPTLC profiles of the extracts and presence of flavonoids were determined. The two propolis } \\
\text { samples exhibited varied activity against the tested microorganisms with MICs ranging from } 0.42 \text { to } 6.67 \mathrm{mg} / \mathrm{ml} \text {, } \\
\text { with Tabora propolis being more active than Iringa propolis. Staphylococcus aureus was the most susceptible } \\
\text { microorganism, while Pseudomonas aeruginosa was the most resistant. Propolis also potentiated the activity of } \\
\text { Gentamicin. Both samples tested positive for flavonoids. However, there were some differences in their HPTLC } \\
\text { profiles. We recommend further studies involving more samples of propolis from various regions of Tanzania to } \\
\text { verify further the observed activity and synergism. }\end{array}$} \\
\hline Received on: $05 / 05 / 2016$ & \\
\hline Revised on: $17 / 07 / 2016$ & \\
\hline Accepted on: 19/10/2016 & \\
\hline Available online: $31 / 01 / 2017$ & \\
\hline Key words: & \\
\hline $\begin{array}{l}\text { Propolis, antimicrobial } \\
\text { activity, Tanzania, } \\
\text { synergism, Staphylococcus } \\
\text { aureus. }\end{array}$ & \\
\hline
\end{tabular}

\section{INTRODUCTION}

Propolis, also referred to as bee glue, is a red to dark brown sticky substance produced by bees and is composed of a resinous mixture of compounds (Stepanović et al., 2003; Ugur and Arslan, 2004). These compounds are produced by bees from bee secretions, beeswax, plant exudates, and other plant parts collected from the surrounding flora (Bankova, 2005; Scazzocchio et al., 2006; Wiȩckiewicz et al., 2013). Propolis contains a variety of compounds, some of which are terpenes, flavonoids and other phenolics (Marcucci, 1995; Bankova et al., 2000). Previous studies have also shown that the chemical

* Corresponding Author

Department of Pharmacognosy, School of Pharmacy, MUHAS,

P.O Box 65013, Dar es Salaam, Tanzania. Tel. No.:+255-689 947708

E-mail:drunyoro@yahoo.co.uk composition of propolis varies with geographical origin, botanical source and bee species (Bankova, 2005; Silici and Kutluca, 2005; Salatino et al., 2011; Fernandes-Silva et al., 2013; Toreti et al., 2013). Propolis serves as a beehive protective barrier against microbial contamination and a sealant for unwanted small gaps in the beehive (Bankova, 2005). This bee product has been used in folklore medicine as an antiseptic, immune system support and a cure for bruises, mouth and throat infections, cancer, inflammation, cardiovascular diseases, respiratory infections and many others (Castaldo and Capasso, 2002; Shruthi and Suma, 2012; Wagh, 2013). It is also used as one of the constituents in health foods and in preparation of chewing gum, beverages, cosmetics, lozenges and skin creams (Banskota et al., 2001; Scazzocchio et al., 2006; Wagh, 2013). Communities in Tabora and Iringa regions in Tanzania use propolis in treating diseases such as hernia, constipation, skin burns and wounds. It is also used as a prophylactic measure for various diseases especially those related to the gastrointestinal tract (Msemo, 2014). 
Literature indicates that propolis is associated with a number of important biological activities including antimicrobial, antioxidant, anticancer, hepatoprotective, anti-inflammatory, immunostimulant, anticariogenic, antiprotozoan, allergenic, antibrowning, antidiabetic and antitumour activities (Ophori et al., 2010; Siripatrawan et al., 2013; Wagh, 2013; Więckiewicz et al., 2013; Wojtyczka et al., 2013a, b; Omar et al., 2016). Furthermore propolis has been reported to exhibit synergism with a number of antibiotics against various bacteria species (Stepanović et al., 2003; Fernandes Júnior et al., 2005; Scazzocchio et al., 2006) and to be active against methicillin resistant Staphylococcus aureus [MRSA] (Darwish et al., 2010).

There is very scanty information regarding Tanzanian propolis though the country is renowned for its beekeeping activity which brings in substantial revenue (Mwakatobe, and Mlingwa, 2006; Mmasa, 2007). A study conducted on propolis from various countries, reported that a sample from Tanzania exhibited antimicrobial activity, with a MIC of $15.62 \mu \mathrm{g} / \mathrm{ml}$ against standard strains of Gram positive bacteria including, Staphylococcus aureus, Staphylococcus epidermidis, Streptococcus pyogenes, Enterococcus faecalis and Bacillus subtilis (Seidel et al., 2008). However, the exact collection area of the studied propolis sample was not indicated. Since the surrounding flora has a great influence on the biological activities of propolis there is a need to study the biological activities of propolis from different parts of Tanzania.

The current study on the antimicrobial activity of Tanzanian propolis was prompted by the need to search for new and more effective antimicrobial agents in this era when antimicrobial resistance (AMR) is an increasingly serious threat to global public health and economy (Levy, 2002; Moyo et al., 2010; WHO, 2014). This is a big challenge in developing countries including Tanzania (Leung et al., 2011; 't Hoen et al., 2014). To aggravate the situation further, the pharmaceutical industries are not enthusiastic anymore to invest in this line despite the fact that there is a lot of new emerging infections due HIV and AIDS (Walsh et al., 2004; Leung et al., 2011; White, 2011).

The aim of the current study was to determine the antimicrobial activity and synergistic effects of propolis samples collected from two regions of Tanzania.

\section{MATERIALS AND METHODS}

\section{Preparation of propolis extracts}

Propolis samples collected from Iringa and Tabora regions were, kindly, provided by Mr. Stephen Msemo, of the Ministry of Natural Resources and Tourism, Dar es Salaam, Tanzania. Fifty grams and $20 \mathrm{~g}$ of propolis from Iringa and Tabora, respectively, were separately powdered using a mortar and pestle and soaked in ethanol $(250 \mathrm{ml}$ and $100 \mathrm{ml}$, respectively) for three days with occasional agitation to facilitate the extraction process. The resultant extracts were separated from the marc by filtration. The extraction process was repeated until the resultant extract was almost colourless. The extracts were dried in vacuo using a Buchi rotary evaporator set at $50^{\circ} \mathrm{C}$. The extracts were stored in a refrigerator, at $4^{\circ} \mathrm{C}$ prior to screening for antimicrobial activity.

\section{Screening for antimicrobial activity \\ Test microorganisms}

Test microorganisms included; Gram +ve bacteria, Staphylococcus aureus (ATCC 25923) and Streptococcus faecalis (ATCC 29212); Gram -ve bacteria including Pseudomonas aeruginosa (ATCC 27853), Proteus vulgaris (ATCC 29905), Salmonella typhi (ATCC 700931), Klebsiella oxytoca (ATCC 700603) and Escherichia coli (ATCC 25922) and the yeasts Candida albicans (ATCC 60193) and Cryptococcus neoformans (ATCC 90112) which were obtained from Muhimbili National Hospital, Dar es Salaam, Tanzania.

\section{Preparation of propolis extract test samples and growth media}

Twenty (20) mg of each propolis extract was dissolved in $1 \mathrm{ml}$ of $10 \% \mathrm{v} / \mathrm{v}$ of Dimethyl sulphoxide (DMSO) in sterile water to make a concentration of $20 \mathrm{mg} / \mathrm{ml}$. Double and normal strength Mueller Hinton Broth (Carl Roth GmbH + Co.KG, Germany) and Sabouraud dextrose broth (HiMedia Laboratories, Pvt Ltd, Mumbai India) were prepared according to manufacturers' instructions.

\section{Determination of minimum inhibitory concentrations (MICs)}

Determination of MICs was accomplished through broth microdilution method as per standard protocol (Wiegand et al., 2008) utilizing a 96 well microtitre plate consisting of twelve columns and eight rows. One hundred (100) $\mu \mathrm{l}$ of the prepared double strength media were placed in each well of the first row of the microtitre plate; whereas $100 \mu \mathrm{l}$ of the normal strength media was placed in each of the rest of the wells. One hundred (100) $\mu \mathrm{l}$ of various test samples prepared in $10 \%$ DMSO were introduced into the first row of the microtitre plate and mixed well, followed by a two- fold dilution down the column. Test microorganisms $(50 \mu 1)$ of appropriate density, were subsequently added to each well to attain a final density of $0.5 \mathrm{MacFarland}$. The adjusted final concentrations of the propolis extracts test samples ranged from $6.67 \mathrm{mg} / \mathrm{ml}$ to $5.2 \times 10^{-2} \mathrm{mg} / \mathrm{ml}$ ), while for positive controls they ranged from $1.64 \times 10^{-3}$ to $6.4 \times 10^{-6} \mathrm{mg} / \mathrm{ml}$ for Gentamicin sulphate and $6.7 \times 10^{-1}$ to $5 \times 10^{-3} \mathrm{mg} / \mathrm{ml}$ for Fluconazole. The final maximum concentration of DMSO in the wells was $3.3 \% \mathrm{v} / \mathrm{v}$; hence this was also the maximum concentration for the wells which were used for the negative control.

The plates were then incubated for 24 hours at $37^{\circ} \mathrm{C}$ for bacteria and $28^{\circ} \mathrm{C}$ for yeasts, after which they were removed from the incubator and $50 \mu \mathrm{l}$ of $0.2 \mathrm{mg} / \mathrm{ml} \mathrm{p}$-iodonitrotetrazolium (INT) was added, followed by further incubation of the plates for 30 minutes. The lowest concentrations which showed no purple colour (indicating absence of growth) were taken as the minimum inhibitory concentrations (MICs). The determination of MICs was done in triplicate. 
Table 1: Final concentrations of combined gentamicin and propolis in the microtitre wells

\begin{tabular}{cccccc}
\hline \multicolumn{2}{c}{ Microtitre plate 1 } & \multicolumn{2}{c}{ Microtitre plate 2 } \\
\hline S/N & Gentamicin $(\mathbf{m g} / \mathbf{m l})$ & Propolis $(\mathbf{m g} / \mathbf{m l})$ & S/N & Gentamicin $(\mathbf{m g} / \mathbf{m l})$ & Propolis $(\mathbf{m g} / \mathbf{m l})$ \\
\hline 1 & $8.21 \times 10-4$ & 3.33 & 9 & $3.21 \times 10^{-6}$ & $1.32 \times 10^{-2}$ \\
2 & $4.1 \times 10^{-4}$ & 1.67 & 10 & $1.60 \times 10^{-6}$ & $6.60 \times 10^{-3}$ \\
3 & $2.05 \times 10^{-4}$ & $8.4 \times 10^{-1}$ & 11 & $8.02 \times 10^{-7}$ & $3.30 \times 10^{-3}$ \\
4 & $1.03 \times 10^{-4}$ & $4.2 \times 10^{-1}$ & 12 & $4.01 \times 10^{-7}$ & $1.65 \times 10^{-3}$ \\
5 & $5.13 \times 10^{-5}$ & $2.1 \times 10^{-1}$ & 13 & $2.0 \times 10^{-7}$ & $8.3 \times 10^{-4}$ \\
6 & $2.56 \times 10^{-5}$ & $1.05 \times 10^{-1}$ & 14 & $1.0 \times 10^{-7}$ & $2.2 \times 10^{-4}$ \\
7 & $1.28 \times 10^{-5}$ & $5.25 \times 10^{-2}$ & 15 & $5.01 \times 10^{-8}$ & $2.1 \times 10^{-4}$ \\
8 & $6.41 \times 10^{-6}$ & $2.63 \times 10^{-2}$ & 16 & $2.5 \times 10^{-8}$ & $1.05 \times 10^{-4}$ \\
\hline
\end{tabular}

Table 2: Minimum Inhibitory concentrations (MICs; $\mathrm{mg} / \mathrm{ml}$ ) of propolis samples for various microorganisms.

\begin{tabular}{cccccccccc}
\hline Test Sample & \multicolumn{10}{c}{ Microorganisms } \\
\cline { 2 - 10 } & E. coli & K. oxytoca & S. aureus & S. typhi & P.aeruginosa & P. vulgaris & S. faecalis & C.albicans & C. neoformans \\
\hline TP extract & 0.84 & 0.84 & 0.42 & 0.84 & - & 1.67 & 0.84 & 1.67 \\
IP extract & 1.67 & 1.67 & - & - & - & 3.34 & - & 6.67 \\
Gentamicin & $2.6 \times 10^{-5}$ & $2.6 \times 10^{-5}$ & $5.1 \times 10^{-5}$ & $5.1 \times 10^{-5}$ & - & $2.6 \times 10^{-5}$ & $2.6 \times 10^{-5}$ & NA & 3.34 \\
Fluconazole & NA & NA & NA & NA & NA & NA & NA & 0.021 & 0.021 \\
$3.3 \%$ DMSO & - & - & - & - & - & - & - & - & - \\
\hline
\end{tabular}

Key: - : No activity; NA: Not applicable, TP: Tabora Propolis, IP: Iringa propolis

\section{Determination of synergistic effect of propolis with gentamicin}

The synergistic effect of propolis with gentamicin was determined by determination of MICs for mixtures of gentamicin and the Iringa propolis extract. One hundred (100) $\mu \mathrm{l}$ of gentamicin $\left(4.9 \times 10^{-3} \mathrm{mg} / \mathrm{ml}\right)$ and $100 \mu \mathrm{l}$ of propolis extract $(20 \mathrm{mg} / \mathrm{ml})$ in $10 \%$ DMSO were properly mixed, then $100 \mu \mathrm{l}$ of the mixture was added to wells in the first row of the microtitre plate containing $100 \mu \mathrm{l}$ of double strength Mueller Hinton Broth, followed by two-fold dilution down each column this was followed by addition of $50 \mu \mathrm{l}$ of bacteria inocula. The final concentrations of propolis and gentamicin in the microtitre plate wells were as shown in the Table 1.

\section{High Performance Thin Layer Chromatography (HPTLC) profiles}

Five (5) $\mu \mathrm{l}$ of $1 \%$ ethanolic solution of each propolis extract was applied on HPTLC glass coated Silica gel $60 \mathrm{~F}_{254}$ plates $(200 \mu \mathrm{m}, 10 \times 20 \mathrm{~cm}$, Merck, Germany) as bands $(8 \mathrm{~mm})$ using Linomat 5 applicator (Camag, Switzerland). The plates were developed for $12 \mathrm{~cm}$ with n-hexane: ethyl acetate (6:4) with chamber saturation. The developed HPTLC plates were dried in air for 30 minutes and scanned at $261 \mathrm{~nm}$ using a TLC scanner (Camag, Switzerland). The plates were sprayed with vanillinsulphuric acid reagent and heated with a stream of hot air until spots were evident.

\section{Determination of the presence of flavonoids}

Shibata's reaction (Ciulei, 1982) was performed on the extracts of propolis samples in order to determine the presence of flavonoids.

\section{RESULTS AND DISCUSSION}

The two propolis samples were sticky and dark brown in colour and on extraction with ethanol the sample from Iringa yielded a brown extract $(23.6 \mathrm{~g} ; 47.2 \%)$ while the Tabora sample gave a dark brown extract $(7.0 \mathrm{~g} ; 35 \%)$.

The minimum inhibitory concentrations of the extracts, as determined by the broth microdilution method, are as indicated in Table 2. In this study, the ethanolic extract of propolis obtained from Tabora displayed activity on almost all tested microorganisms (MIC $0.42-1.67 \mathrm{mg} / \mathrm{ml}$ ) with only Pseudomonas aeruginosa being resistant to this extract. This is in agreement with a previous study on Tanzanian propolis; although in that study the specific area where propolis was collected was not indicated (Seidel et al., 2008). On the other hand the ethanolic extract of propolis from Iringa was able to inhibit growth of five out of nine microorganisms tested, with MICs ranging from 1.67 to $6.67 \mathrm{mg} / \mathrm{ml}$. This extract was not active against $S$. aureus, $S$. typhi, $P$. aeruginosa and $S$. faecalis at the tested concentrations. The observed MICs for both samples were several times higher when compared to a previous report on Tanzanian propolis (Seidel et al., 2008), where MICs ranged from 15.62 to $250 \mathrm{mg} / \mathrm{l}$ for Gram $+v e$ bacteria. The MICs observed in this study were somehow similar to those reported in another study on propolis from Italy (Scazzocchio et al., 2006).

The Gram + ve bacterium, $S$. aureus, was the most susceptible microorganism to Tabora propolis, with MIC of 0.42 $\mathrm{mg} / \mathrm{ml}$; however, it was resistant to Iringa propolis. The variation in the observed antimicrobial activity between the two propolis samples studied is in line with previous reports on other studies. For example a study done on Egyptian propolis collected from four different localities reported varied antimicrobial activity (Hegazi and Abd El Hady, 2001). A similar observation was also noted when propolis was collected from two localities in Jordan differing in their natural vegetation (Darwish et al., 2010). Therefore, the variation in activity between propolis from Iringa and that from Tabora could be due to the varied vegetation and climatic conditions between the two regions. Iringa Region is situated in the southern highlands with a cool weather while 
Tabora Region is around the central part of Tanzania with a warmer climate and somehow varied vegetation.

Propolis contains varied groups of compounds; some of which, including flavonoids, have been reported to exhibit antimicrobial activity. In this study, both Tabora and Iringa propolis samples gave a positive result for Shibata's reaction, with the Tabora sample responding with a more intense colour than that of Iringa, indicating that it contained more flavonoids and probably, that is why it was more active. The HPTLC scans for the two samples of propolis are as shown in Figure 1. They had some similarities as could be expected; however, there are some differences, especially at the origin of the HPTLC plate, where the Tabora sample showed two unresolved peaks ( $a$ and $b$ ) while the Iringa sample showed only one peak (a). The next unresolved peaks ( $c$ and $d$ ) though present in higher concentrations in the Tabora sample, they were present in trace amounts in the Iringa sample. Moreover two peaks (e and $\mathrm{f}$ ) seen in the Iringa sample were absent in the Tabora sample. On visualization of the spots with vanillin-sulphuric acid reagent (Fig. 2) the three spots which were observed in the Iringa propolis (4, 8 and 11) could not be detected in the Tabora sample. Also the four spots seen in the Tabora propolis (spots 6, 7, 9 and 10) were not seen in the Iringa sample. Since biological activities are determined by the bioactive constituents of the samples the differences in the antimicrobial activity of the two propolis samples could have been attributed to the observed different chemical profiles. With regard to synergism with antibiotics, this study has revealed a decrease in the MIC of gentamicin when it was combined with different proportions of the extracts of propolis from Iringa, whereby no growth of bacteria was noted at a concentration as low as $2.5 \times 10^{-8} \mathrm{mg} / \mathrm{ml}$ for gentamicin and $1.05 \times 10^{-4} \mathrm{mg} / \mathrm{ml}$ for propolis. However, Pseudomonas aeruginosa was resistant to all concentrations of the combination. This observation is in agreement with what was reported for Brazilian propolis (Fernandes Junior et al., 2005), Spanish propolis (Scazzocchio et al., 2006) and Polish propolis (Wojtyczka et al., 2013a).

In the previous studies, synergism was mostly noted between ethanolic extract of propolis and antimicrobial agents which interfere with bacterial protein synthesis such as chloramphenicol, gentamicin, tetracycline, and vancomycin (Fernandes Júnior et al., 2005; Scazzocchio et al., 2006). The combination of propolis with antibiotics can reduce drug dosages, minimize drug side effects, and decrease chances of drug resistance (Stepanović et al., 2003; Fernandes Júnior et al., 2005; Scazzocchio et al., 2006). Furthermore, it has been reported that therapeutic application of propolis does not induce microbial resistance nor does it destroy useful microflora (Ramanauskiene et al., 2009). This implies that propolis may become a reliable antimicrobial agent in this era of AMR; hence the need for further investigations.

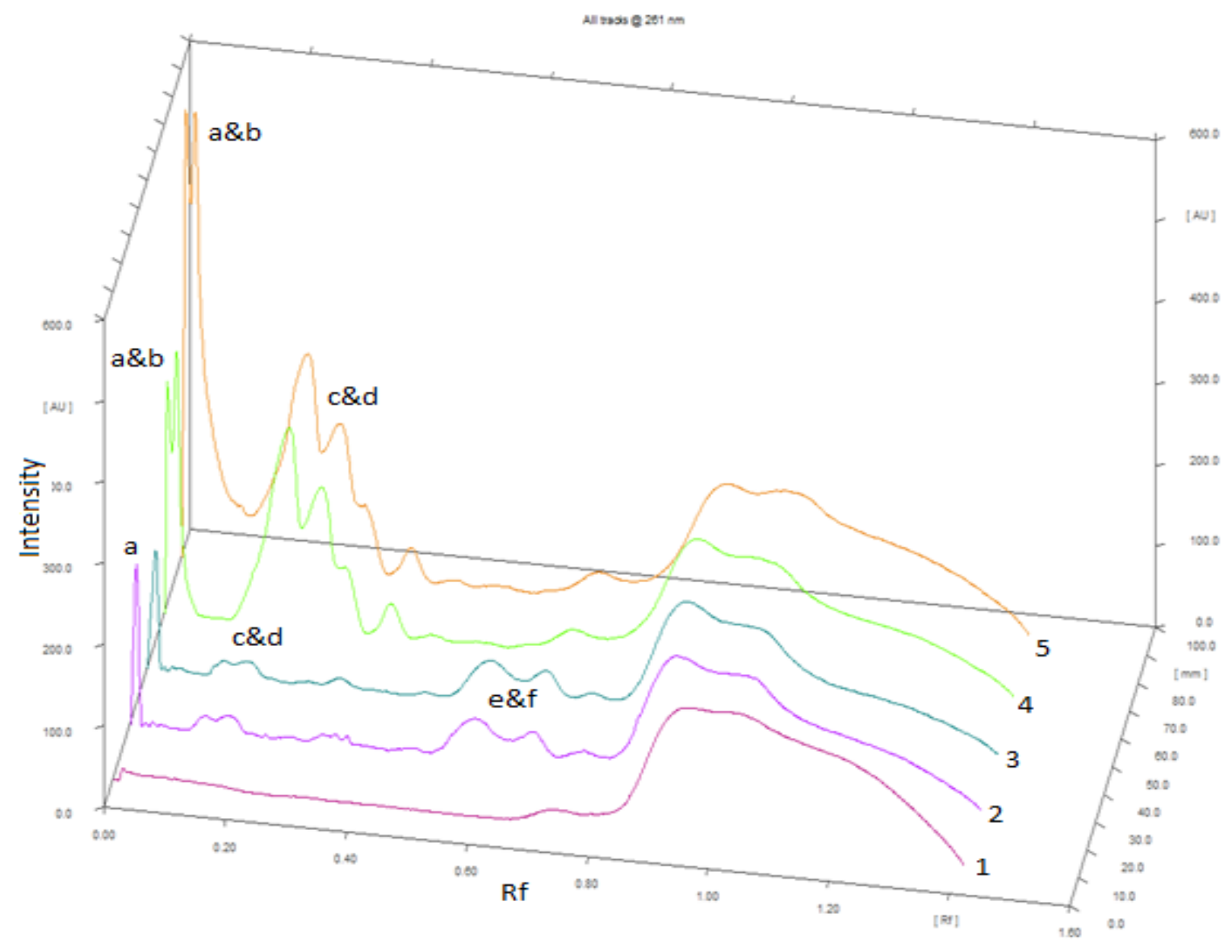

Fig. 1: HPTLC scans for Iringa propolis (Tracks 2 and 3), Tabora propolis (Tracks 4 and 5) and ethanol (Track 1). 


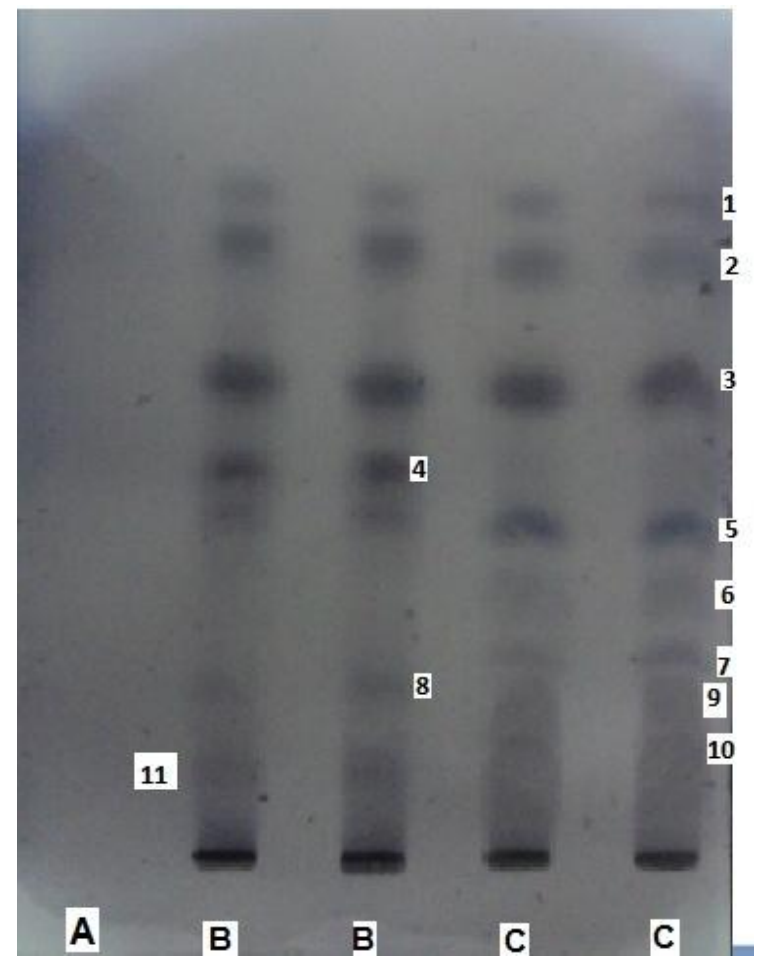

Fig 2: HPTLC chromatogram of ethanolic extracts of Iringa and Tabora propolis A: Ethanol, B: Iringa sample, C: Tabora sample, Spots 1-10

\section{CONCLUSION}

Samples of propolis from Iringa and Tabora regions showed antimicrobial activity with propolis from Tabora being comparatively more active than that from Iringa, and both samples gave a positive test for flavonoids. Furthermore, the activity of gentamicin was increased by propolis; an attribute which could be utilized in drug discovery especially for those microorganisms which have already shown resistance to the available antimicrobial agents. The observed differences in antimicrobial activity could be due to differences in their chemical constituents as indicated by their HPTLC scans and TLC profiles. Therefore it is worth conducting further studies on propolis samples from other parts of Tanzania with regard to their antimicrobial and synergistic effects, which will form a basis for their medicinal exploitation in future.

\section{Financial support and sponsorship: Nil.}

Conflict of Interests: There are no conflicts of interest.

\section{REFERENCES}

Bankova V. Review Recent trends and important developments in propolis research. Evid. Based Complement. Alternat. Med. 2005; 2: 29 -32 .

Bankova VS, De Castro SL, Marcucci MC. Propolis: Recent advances in chemistry and plant origin. Apidologie 2000; 31:3-15.

Banskota AH, Tezuka Y, Kadota S. Recent Progress in Pharmacological Research of Propolis. Phytother Res 2001; 15: 561-57.

Castaldo S, Capasso F. Propolis, an old remedy used in modern medicine. Fitoterapia 2002; Supplement 1: S1-S6.
Ciulei I. 1982. Methodology for analysis of vegetable drugs. Practical manuals on the industrial utilization of medicinal and aromatic plants. $1^{\text {st }}$ Ed., Bucharest, Romania, Ministry of Chemical Industry.

Darwish RM, Fares RJA, Zarga MHA, Nazer IK. Antibacterial effect of Jordanian propolis and isolated flavonoids against human pathogenic bacteria. Afr J Biotechnol 2010; 9(36): 5966-5974.

Fernandes Júnior A, Balestrin EC, Betoni JEC, Orsi RO, Cunha MLRS, Montelli AC. Propolis: anti-Staphylococcus aureus activity and synergism with antimicrobial drugs. Montelli. Mem Inst Oswaldo Cruz, Rio de Janeiro 2005; 100(5): 563-566.

Fernandes-Silva C; Freitas, J-; Salatino A; Salatino M. Cytotoxic activity of six samples of Brazilian propolis on Sea Urchin (Lytechinus variegatus) Eggs. Evid. Based Complement. Altern. Med. 2013, [ONLINE] Available at: http://dx.doi.org/10.1155/2013/619361. [Accessed 12 December, 2014].

Hegazi AG, Abd El Hady FK. Egyptian Propolis: 1 Antimicrobial Activity and Chemical Composition of Upper Egypt propolis. Z Naturforsch 2001; 56c: 82-88.

Levy SB. The 2000 Garrod lecture. Factors impacting on the problem of antibiotic resistance. J Antimicrob Chemother 2002; 49:25-30.

Leung E, Weil DE, Raviglionea M, Nakatania H. The WHO policy package to combat antimicrobial resistance. Bull World Health Organ 2011; 89:390-392.

Marcucci MC. Propolis: Chemical composition, biological properties and therapeutic activity. Apidologie 1995, 26, 83-99.

Mmasa JJ. 2007. Economic analysis of honey production and marketing in Hai district, Kilimanjaro, Tanzania a dissertation submitted in partial fulfilment of the requirements for the Degree of Masters of Science in Agricultural Economics of Sokoine University of Agriculture. Morogoro, Tanzania. [ONLINE] Available at: http://suaire.suanet.ac.tz:8080/xmlui/bitstream/handle/123456789/269/Joel \%20Johnson\%20Mmasa\%202007.pdf?sequence=1 andis Allowed=y

[Accessed 12 December, 2014].

Moyo SJ, Aboud S, Kasubi M, Lyamuya EF, Maselle SY. Antimicrobial resistance among producers and non-producers of extended 
spectrum beta lactamases in urinary isolates at a tertiary hospital in Tanzania. BMC Res Notes 2010; 3: 348.

Msemo SE. Senior Beekeeping Officer. Tanzania Forest Services (TFS) Agency Ministry of Natural Resources and Tourism. Personal communication, November, 2014.

Mwakatobe A, Mlingwa C. 2006.Tanzania-The status of Tanzanian honey Trade-Domestic and International Markets. [ONLINE] Available at: http://www.tanzaniagateway.org/docs/the_status_of_tanzanian_honey_tra de_markets_nov2006.pdf. [Accessed 12 December, 2014].

Omar RMK, Igoli J, Gray JI, Ebiloma GU, Clements C, Fearnley J, Ebel RAE, Zhang T, De Koning HP, Watson DG. Chemical characterisation of Nigerian red propolis and its biological activity against Trypanosoma Brucei. Phytochem Anal 2016; 27: 107-115.

Ophori EA, Eriagbonye BN, Ugbodaga P. Antimicrobial activity of propolis against Streptococcus mutans. Afr J Biotechnol 2010; 9(31): 4966-4969.

Ramanauskiene K. Inkeniene AM. Savickas A, Masteikova R, and Brusokas V. Analysis of the antimicrobial activity of propolis and lysozyme in semisolid emulsion systems. Acta Pol Pharm 2009; 66, 681688.

Salatino A, Fernandes-Silva CC, Righi AA, Salatino MLF. Propolis research and the chemistry of plant products. Nat Prod Rep2011, 28, 925-936.

Scazzocchio F, D'Auria FD, Alessandrini D, Pantanella F. Multifactorial aspects of antimicrobial activity of propolis. Microbiol Res 2006; 161:327-333.

Seidel V, Peyfoon E, Watson DG, Fearnley J. Comparative Study of the antibacterial activity of propolis from different geographical and climatic zones. Phytother. Res. 2008; 22: 1256-1263.

Shruthi E, Suma BS. Health from the hive: Potential uses of propolis in general health. Int J Clin Med 2012; 3: 159-162.

Silici S, Kutluca S. Chemical composition and antibacterial activity of propolis collected by three different races of honeybees in the same region. J Ethnopharmacol 2005; 99:69-73.

Siripatrawan U, Vitchayakitti W, Sanguandeekul R. Antioxidant and antimicrobial properties of Thai propolis extracted using ethanol aqueous solution. Int J Food Sci Tech 2013; 48: 22-27.

Stepanović S, Antić N, Dakić I, Švabić-Vlahović M. In vitro antimicrobial activity of propolis and synergism between propolis and antimicrobial drugs. Microbiol Res 2003; 158: 353-357.

't Hoen EFM, Hogerzeil HV, Quick JD, Sillo HB. A quiet revolution in global public health: The World Health Organization's Prequalification of Medicines Programme. J Public Health Pol. 2014; 35(2): 137-161.

Toreti VC, Sato HH, Pastore GM, Park YK. Recent progress of propolis for its biological and chemical compositions and its botanical origin. Evid. Based Complement. Alternat Med 2013; [ONLINE] Available at: http://dx.doi.org/10.1155/2013/697390. [Accessed 12 December, 2014].
Ugur A, Arslan S. An in vitro study on antimicrobial activity of propolis from Mugla Province of Turkey. J Med Food 2004; 7 (1): 90-94.

Wagh VD. Propolis: A wonder bees product and its pharmacological potentials. Adv Pharmacol Sci; 2013; [ONLINE] Available at: http://dx.doi.org/10.1155/2013/30824 [Accessed 12 December, 2014].

Walsh TJ, Groll A, Hiemenz J, Fleming R, Roilides E, Anaissie E. Infections due to emerging and uncommon medically important fungal pathogens. Clin Microbiol Infect 2004; 10 (Suppl. 1): 48-66.

White AR. Effective antibacterials: at what cost? The economics of antibacterial resistance and its control. J Antimicrob Chemother 2011; 66: 1948-1953.

WHO, 2014, Antimicrobial resistance global report on surveillance.[ONLINE] Available at: www.who.int/drugresistance/documents/surveillancereport/en/ [Accessed 10 February, 2015].

Więckiewicz W, Miernik M, Więckiewicz M, Morawiec T. Does propolis help to maintain oral health? Evid Based Complement Alternat Med 2013; [ ONLINE] Available at: http://dx.doi.org/10.1155/2013/351062 [Accessed 04 November, 2014].

Wiegand I, Hilpert K, Hancock REW. Agar and broth dilution methods to determine the minimal inhibitory concentration (MIC) of antimicrobial substances. Nature Protocols 2008; 3(2): 163-175.

Wojtyczka RD, Dziedzic A, Idzik D, Kępa M, Kubina R, Kabała-Dzik A, Smoleń-Dzirba J, Stojko J, Sajewicz M, Wąsik TJ. Susceptibility of Staphylococcus aureus clinical isolates to propolis extract alone or in combination with antimicrobial drugs. Molecules 2013a; 18: 9623-9640.

Wojtyczka RD, Kepa M, Idzik D, Kubina R, Kabala-Dzik A, Dziedzic A, Wasik TJ. In vitro antimicrobial activity of ethanolic extract of polish propolis against biofilm forming Staphylococcus epidermidis strains. Evid Based Complement Alternat Med 2013b; [ONLINE]. Available at: http://dx.doi.org/10.1155/2013/590703 [Accessed 04 November, 2014].

\section{How to cite this article:}

Runyoro DKB, Ngassapa OD, Kamugisha A. Antimicrobial Activity of Propolis From Tabora and Iringa Regions, Tanzania and Synergism with Gentamicin. J App Pharm Sci, 2017; 7 (01): 171176. 